\title{
Chlordiazepoxide Measurement
}

National Cancer Institute

\section{Source}

National Cancer Institute. Chlordiazepoxide Measurement. NCI Thesaurus. Code C75371.

The determination of the amount of chlordiazepoxide present in a sample. 